Abstracta Iranicacta Iranica

Revue bibliographique pour le domaine irano-aryen

Volume 28 | 2007

Comptes rendus des publications de 2005

\title{
Suse, terres cuites islamiques. Paris et Gand, Snoeck/ Musée du Louvre, 2005, 262 p., ill.
}

\section{Carine Juvin}

\section{(2) OpenEdition}

1 Journals

\section{Édition électronique}

URL : http://journals.openedition.org/abstractairanica/11462

DOI : 10.4000/abstractairanica. 11462

ISSN : 1961-960X

Éditeur :

CNRS (UMR 7528 Mondes iraniens et indiens), Éditions de l'IFRI

\section{Édition imprimée}

Date de publication : 15 mai 2007

ISSN : 0240-8910

\section{Référence électronique}

Carine Juvin, « Suse, terres cuites islamiques. Paris et Gand, Snoeck/Musée du Louvre, 2005, 262 p., ill. », Abstracta Iranica [En ligne], Volume 28 | 2007, document 225, mis en ligne le 18 septembre 2007, consulté le 25 septembre 2020. URL : http://journals.openedition.org/abstractairanica/11462 ; DOI : https://doi.org/10.4000/abstractairanica.11462

Ce document a été généré automatiquement le 25 septembre 2020.

Tous droits réservés 


\title{
Suse, terres cuites islamiques. Paris et Gand, Snoeck/Musée du Louvre, 2005, 262 p., ill.
}

\author{
Carine Juvin
}

1 Aboutissement du travail de récolement et d'étude mené par G. Joel, ce catalogue rassemble le matériel en céramique non glaçurée, issu des niveaux islamiques des fouilles de Suse et conservé au département des Arts de l'Islam du musée du Louvre.

2 Une introduction par S. Makariou retrace l'histoire des fouilles françaises à Suse, l'arrivée des pièces au Louvre et présente les caractéristiques et l'intérêt de cette collection.

3 Le corpus de 337 pièces est réparti par typologie : cruches, pichets, jarres et supports, lampes, et objets divers (jeux et jouets, figurines, moules à sucre, éolipiles...). Une section particulière est consacrée aux objets inscrits : textes magiques en araméen et textes en arabe, la plupart non déchiffrés, exceptées deux correspondances amoureuses, témoignages exceptionnels sur la vie quotidienne des classes aisées à l'époque abbasside.

4 Ce catalogue est un premier jalon dans la publication du matériel islamique issu des fouilles de Suse, qui devrait se poursuivre avec un volume dévolu aux céramiques à décor de glaçure.

\section{INDEX}

Thèmes : 5.1. Monde iranophone 
AUTEURS

CARINE JUVIN

Musée du Louvre - Paris 